\title{
Blasts 30,000 or Less of Peripheral Blood White Cells
}

National Cancer Institute

\section{Source}

National Cancer Institute. Blasts 30,000 or Less of Peripheral Blood White Cells. NCI

Thesaurus. Code C153117.

A quantitative microscopic finding indicating that 30,000 or fewer nucleated cells in a peripheral leukocyte sample are immature mononuclear cells. 